\title{
Investigating university students' adaptation to a digital learner course portfolio
}

\author{
Lopez-Fernandez, Olatz ${ }^{\text {1a }}$, Rodriguez-Illera Jose Luis ${ }^{b}$ \\ ${ }^{a}$ Departament de Metodologia de les Ciències del Comportament, Facultat de \\ Psicologia, Universitat de Barcelona, Passeig de la Vall d'Hebron 171, 08035 \\ Barcelona, Spain \\ ${ }^{b}$ Departament de Teoria i Història de l'Educació, Facultat de Pedagogia, \\ Universitat de Barcelona, Spain, Passeig de la Vall d'Hebron 171, 08035 Barcelona, \\ Spain
}

Corresponding author: Tel.: +34 93 3125074; Fax: +34 934021359

E-mail address: olatzlopez@ub.edu (L-F. Olatz) 


\begin{abstract}
Digital learner portfolios are of growing importance in higher education as the sector seeks new teaching-learning-assessment methods which promote students' autonomy as managers of their own virtual learning environment. The purpose of this study was to analyze descriptively the undergraduate students' perceptions, attitudes and behaviour when using an eportfolio to support their learning and assessment in practice based courses at two traditional Spanish universities. The participants were 88 students, who were studying through a blended-learning mode. Data were collected through questionnaires: a computer experience survey, another which examined the psychological, pedagogical and technological dimensions of eportfolios use. Further, an individual overall reflection was obtained from each student to help gain an understanding of their experiences of using the eportfolio. A mixed-method analysis was applied in order to study the impact of this technological innovation on students and their satisfaction. The results showed that the students had positive opinions and self-efficiency through the eportfolio as a tool to manage their learning and assessment during a semester, especially from the second month of use. However, the expected impact on their learning was not so significant. Nevertheless, the students emphasised that the eportfolio was valuable as a personal developmental learning tool.
\end{abstract}

Key words: ePortfolio, Higher education, Teaching/Learning strategies, Evaluation methodologies, Web-based learning. 


\section{Introduction and literature review}

Universities are implementing new strategies supported by technology for teaching, learning and making student assessment more learner-centred, in order to focus the educative process on a future lifelong and life-wide learner (Laurillard, 1993; Schank, 1997; Kimball, 1998; Collis \& Moonen, 2001; Cuthell, 2002; Bates, 2003; Preston, 2005). This socio-educational change towards students' perspective has led to the implementation of strategies that promote students' personal development, and help them to plan for continuing education, based on an evaluation of their competences. Such skills include: learner autonomy, self-reliability, the ability to use a range of strategies to construct their competencies, and having the flexibility to adapt these strategies to new training contexts.

\subsection{Digital learner portfolios}

In this educative context centred on students' learning achievements, eportfolios appeared in the nineties as a pedagogical strategy based on monitoring students' competencies in order to accredit learning (Niguidula, 1993; Kankaanranta, Barrett \& Hartnell-Young, 2001).

In education, eportfolios are recognised as being a technological tool that allows the student to manage their learning experience. Simultaneously, it helps teachers to observe students' work and their processes of learning during a period of time. The main pedagogic potentiality of these systems is their role in assessment as students are able to manage their progress through learning tasks while being supported by their teachers through these sorts of technological devices. Therefore, teacher teams can use this technology to develop a facilitator role, and to support students' activities and help them to work through specific assessment schedule. In these terms, eportfolios are categorized as a course portfolio, supported by an electronic environment where the students are documenting and reflecting through the ways in which they achieve their outcomes, guided by teachers and the assessment criteria.

The concept of educative eportfolio or digital portfolio is used along with other similar terms such as: efolio (Cambridge, in press), webfolio or web portfolio (Chen, Liu, Ou, 
\& Lin, 2001; Kimball, 2003), virtual portfolio (Sorensen \& Takle, 1999), etc. It refers to a private virtual space (usually in a web-based environment) which contains a collection of digital products (artefacts and reflections) to demonstrate competencies in a field of knowledge to a teacher, a colleague, a professional or a community. In the case of academic digital portfolios, Barrett (2003) describes the learner eportfolio when the student is the owner of this virtual learning environment based on his/her own work. This author (2004) considers that there is a considerable difference between the eporfolio and the assessment management systems, as in the first case the locus of control is the student and in the second it is the institution. However, in a formal educational context which has a great number of students per course and learning is supported by a blended strategy, digital learner portfolios are usually a mid-term between traditional portfolios and sophisticated online assessment management systems. Specifically, its objectives are:

1) to give the student a personal web-based space to store, classify and/or select his or her learning products (by logging with a user name and password),

2) to offer the student to be supported through the Internet by a teacher team of facilitate that learning achievements based on scheduled assessment criteria,

3) to enable the student to self-manage his or her academic assignments (in compulsory or optional modalities, individual or group mode, etc.) and communications (by email, forums or chats, etc.) in order to be more autonomous in their learning management.

\subsection{Electronic platforms for digital learner course portfolios}

Since 2000, few open source web-based platforms have appeared for implementing eportfolios. On the one hand, the first was OSPI ("Open Source Portofolio Initiative") in 2003, based on a model by University of Minessota (USA). This platform offered a personal eportfolio for North-American university students with three main options: enter (information), share (products) and view (other eportfolios). Nowadays it is called OSP and it maintains the open code but with a more complex web-based eportfolio system, similar to virtual campus structure. Another well-known open source portfolio software is ELGG created by Tosh \& Werdmuller (2005), which is based on a social networking platform that offers blogging, networking, community, collecting and sharing features, but it is more addressed to an eportfolio used in a collaborative 
strategy (Tolsby, 2001). Recently, it has appeared MAHARA, an open source eportfolio created in mid 2006 for Massey University, Auckland University of Technology, The Open Polytechnic, and Victoria University of Wellington (New Zealand). It has a modular and extensible architecture, which could be integrated into a wider virtual learning platform as MOODLE ("Modular Object Oriented Developmental Learning Environment", Dougiamas \& Taylor, 2002). On the other hand, open source virtual campus software has also been used adapted to eportfolios, several commercial, homegrown platforms and hybrids have been designed for higher education institutions, such as those obtained and described by ePortfolio Consortium in its ePortfolio White Paper (2003) and Handbook of Research on ePortfolio (Jafari \& Kaufman, 2006). However, analysing these referential documents, few empirical investigations have been undertaken in digital learner portfolios for assessing university students in an academic course, and fewer still have been conducted with longitudinal or more controlled methodologically designs. One reason is probably the novelty of this educational phenomenon which facilitates descriptive research and study cases.

\subsection{Student achievement with a digital learner portfolio}

In 2000 scientific empirical research that focused on digital learner portfolios, started to be published (Cambridge, 2001; Chen et al., 2001). As another computer-mediated educative device, eportfolios have potential in the process of teaching, learning and assessment, and once the main technological platforms were implemented, the researchers focused their attention on the role of the teacher with this innovation, and in the process of instruction (Barrett, 2005). Little research has explored the student's perspective in order to examine how eportfolios affect their academic performance and course-related behaviour.

Chen et al. (2001) analyzes a learning eportfolio as a tool to assess the learning process, and their results showed that for the students the application of ICT in the creation of eportfolios helped them to control their learning; in addition, the effectiveness of the communication channel and the media used in their results of learning were also valued. According to Chen, Ou, \& Wang (2003), teachers could handle and guide with a digital learner portfolio a program of online learning, collaborative in type, in which a large number of students participate (approximately 100 per teacher). Hope (2005) considers 
that an optimal digital portfolio reflects the understanding and behaviour of the student and this is the reason for carefully doing the assessment. Del duca \& Duke (2006) used the digital portfolios in medical education as a system of assessment based on the student work which required a reflective dynamic where they had to optimize the level of their abilities and attitudes thereby obtaining positive results, especially in reflection. Meeus, Questier, \& Derks (2006), from Vrije Universiteit Brussel created an institutional digital portfolio to complement the evaluation of competences directed at educative innovations. They used an open-code platform and the results were positively evaluated by their students. Spendlove \& Hooper (2006), from the School of Education of the University of Manchester, used the production of digital portfolios with their students as a technological activity in the curriculum of initial degree students. This development tool promoted creativity, reflective work, design practice with an educative structure, as well as the development of technological abilities.

In conclusion, the main results of the impact of eportfolios on universities address their vision, assessment, technology, logistics and cultures (Cambridge, 2001). However, in relation to their impact on students, the main role of eportfolios is to enhance learning through reflection. This innovation helps students to manage artefacts and learning outcomes, to select evidences to achieve standards, and to digitally produce a more enriched learning experience. In the last term, the eportfolios helps students to be selfawareness of the educative goals achieved over the duration of an academic endeavour (Zubizarreta, 2004: 4) and support personal development and reflective learning (Stefani, Manson, \& Pegler, 2007).

\section{Rationale of the empirical research}

This research is focused using a pedagogical model of an academic digital learner course portfolio for a traditional university, supported by a web-based environment adapted as an eportfolio. This technological tool and the methodology for implementing it, aim to promote the undergraduate's learning management and assessment with the support of a teacher team as facilitators. For its development, it was necessary to select a flexible web-based platform to implement this private, virtual environment with options to store, view and share being managed by the student, as the main point in the concept of an eportfolio is the student's ownership, guaranteeing the responsibility for 
his or her learning achievement. The student must control web-based environment, learning products, communications, guidance and assessment, in order to self-regulate his or her own learning process by being progressively more autonomous.

A pedagogical model for assessing digital learner portfolio was selected (Castelló \& Monereo, 2000) that is based on initial common information between students and teachers related to the course: they agree on objectives and assessment criteria, the compulsory and optional assignments and reflections, the revision process, and the digital format to store and present their final productions. Our design was based on a proposal of pedagogical criteria for digital portfolios in higher education (López, 2008), which considers the basis of an eportfolio in three macro-criteria: its context (multimedia and instructional design), its components (product -artefacts, reflections and standards- and process -assessment, feedback and presentation- of learning components), and its agents (learner, peers, and their interaction). To implement the model, two different platforms were used: in the University of Barcelona (UB) Moodle was selected, and in the Autonomous University of Barcelona (UAB) their own homegrown platform was selected. In both cases the management systems enabled the researchers to create an open, flexible and engaging online individual web-based environment for supporting the pedagogical characteristics of a digital learner portfolio: self-management, communication and documentation. Apart from these main platforms other pedagogical resources were developed to support the innovation, such as online tutorials with Note Taker (http://www.gream.org/docenciaUB/portdig/).

The eportfolios were used following the same methods of learning and assessment, based on previously scheduled tasks (artefacts) with their reflections, moments for assessing these learner productions (formative assessment) and a final student task (summative assessment), with an overall reflection related to this innovation. The implementation was supported through an induction process guided by an eportfolio tutor, who was supporting students' tasks and assessment, forming a teacher team with the main faculty responsible. The objective of the research was to observe student opinions and behaviour with an eportfolio during a semester, to describe the process of students' adaptation to this technological innovation and their final satisfaction. The final purpose was to illustrate a new practice on a web-based and learner-centred learning strategy, focused on undergraduate university student assessment. 


\section{Method}

This exploratory research is a pre-experimental study based on the introduction of a digital learner course portfolio as a specific assessment methodology at University. The multiple techniques to recollect and analyze the data have a mixed-method approach with a sequential explanatory strategy (Creswell, 2003), integrating quantitative and qualitative dimensions to understand in more depth the phenomenon being studied (Todd, Nerlich, McKeown, \& Clarke, 2004). This investigation examines undergraduate students from two educational institutions who were invited to participate in this research, when they were studying one instrumental subject in a blended learning mode with the support of ICT through an eportfolio: "Investigation in Educative Media" (from Audiovisual Communication grade in UB), "Methodology of Scientific Work" (from Library Science and Documentation grade in UB), and "Practicum I" (from Psychopedagogy grade in UAB). In conclusion, the final sample was composed by the students who agreed to participate during the semester.

\subsection{Participants}

Data was collected from 88 undergraduate students, 57 were women and 31 men, aged $18-46$ years $(M=26.31, S D=5.66)$ from both Universities, characterized as being public, traditional and renowned for their academic competence.

\subsection{Materials}

First of all, an ad hoc computer experience survey was created to obtain information about the students' level of use of the technologies. The questionnaire was made up of ten closed-ended items: one half for questions with a yes/no format of response and, the other half with five multiple-choice questions. The survey collected three kinds of information: (a) the socio-demographical data of the students, (b) their general use of ICT (e.g., having a computer with Internet at home; main place to connect to Internet; frequency and purpose of connection), (c) their use of ICT applied to learning and assessment (e.g., use of CD-Rom for learning, use of Internet for learning, grade of their satisfaction, use of Internet for being assessed). In both institutions students were 
familiar with other web-based environments for learning ("Dossiers electrònics" a home-grown platform in UB and "Campus virtual" with home-grown platform Autònoma Interactiva in $\mathrm{UAB}$ ), and they were not students in their first academic year. The data were analysed statistically with the computer software SPSS (v.12). Statistical relationships were explored among the variables and main participants' characteristics: cohorts from each university, gender and age groups. However, independently of computer literacy skills, the research was also interesting in finding out if the students were prepared to use the technology as an autonomous tool to manage their own learner productions and, above all, their assessment process.

Secondly, students responded to ad hoc questionnaires delivered on a monthly basis that followed their opinion regarding the nature of digital learner portfolio and their progressive adaptation. Each questionnaire had three parts with approximately eight closed-ended items and two open-ended questions: (a) identical socio-demographical data, (b) specific psychological issues and (c) specific pedagogical issues. Psychological issues were examined through the students' expression of feelings in the eportfolio, which were gathered through the entire course, along with the main opinion about the innovation, and the autonomous premises. Pedagogical issues were analyzed deeply, and were related to different characteristics of this innovation (e.g., criteria of assessment, expectations, previous experience with portfolios, influence in their learning, perception of eportfolio support during the semester, main elements of the eportfolio and grade of satisfaction). The data was analyzed descriptively and statistical relationships were also explored among relevant variables related to eportfolio and main participants' characteristics. Finally, an exploratory factor analysis was applied to variables related to the first test, the computer experience survey, and the last eportfolio ad hoc questionnaire, in order to understand in depth the structure and interrelation of these variables, and determine if the information could be condensed into a set of factors related to general use of ICT and in relation to specific use of eportfolios.

Thirdly, before finishing the semester, an overall reflection from every student regarding their experience using eportfolios in a course for learning and assessment was obtained though the same platform. This served as a synthesis of student production contained in the eportfolio. The objective of this last textual document was to generate an open student' opinion that explored expectations of the system, and the students' 
perceptions related to the eportfolio, including advantages and disadvantages. The data were analysed qualitatively with ATLAS-ti (v.5) (Pidgeon \& Henwood, 1996), in order to identify the main code categories related to first pedagogical experience with a course digital learner portfolio in a traditional University.

\subsection{Procedures}

Students from both institutions completed the questionnaires during the Spring 2005 semester. The computer experience survey was administered only once at the beginning of the semester by one of the researchers, when the main teacher informed students about this innovation and this investigation, asking for their permission to be participants. Then, during the semester, every month (February, March, April and May) the ad hoc questionnaires were administered, addressing the eportfolios impact on students. In the last week of May, the end of the semester, the overall individual reflection was obtained by researchers from the digital learner portfolios platforms.

\section{Results}

\subsection{Computer experience survey}

A basic student profile of students' use of ICT was obtained, in order to implement the eportfolio. The univariate results of this questionnaire showed that students were prepared for using an eportfolio as a platform for supporting their learning process (see table 1). The majority had computers with an Internet connection at home, using it daily to communicate and working. However, only a third of them had experienced learning and assessment through Internet, and their degree of satisfaction was intermediate (item measured from 1, being low satisfaction, to 3, being high satisfaction, with the result: $M=2.04 ; S D=0.7)$.

Furthermore, statistical relationships were explored among the variables of this questionnaire and main participants' characteristics, but a significant statistical difference was only found in relation to university cohort group. It was in the item concerning having experience in learning by Internet $(\chi 2=6,091$, df $=1 ; p<0,05)$, where students from UB $(31,2 \%)$ had learnt more by this technology than UAB students $(2,6 \%)$. However, this variable was not as relevant as others as: having computer at 
home, access and knowledge using internet, etc. This fact let us treat the group of participants as a unit in their computing experience.

\subsection{Ad hoc questionnaires about eportfolios}

The monthly ad hoc questionnaires addressed to eportfolio owners informed the following descriptive results:

\subsubsection{Psychological issues in learning with eportfolio}

As regards psychological issues with the eportfolio (see table 2), personal feelings from the beginning were divided in two opposite positions: positive feelings were shown by half of the students who stated that they were calm, self-confident and understood clearly the innovation, while the other half showed negative feelings such as insecurity, confusion and boredom. However, these divided feelings disappeared during the second month, where most of them $(79.2 \%)$ had positive feelings. At that point, they started to become familiar with the platform and, above all, with the assessment methodology. The initial opinions about the main advantage of an eportfolio were (according to student preference): the innovative VLE based on their work (53.25\%), the formative assessment methodology through a digital learner course portfolio (24.2\%), and the autonomy achieved by the learner with the eportfolio (22.55\%); and the initial opinions related to the main disadvantage of eportfolios were (also according to student preference): dedication, understood as amount of time working on the eportfolio (42.27\%), novelty in the sense of uncertainty (33.23\%), and problems of accessibility to internet $(24.49 \%)$. In the last term, the majority of the students did not plan their learning $(77.6 \%)$, but half of our sample recognized that the eportfolio was helping them to self-manage their learning process, promoting their self-responsibility in their assessment achievements.

\subsubsection{Pedagogical issues in learning with eportfolio}

For pedagogical issues with the eportfolio (see table 3), it was observed that from the beginning of the semester, students valued knowing the assessment criteria (78.7\%), and they had positive expectations of being assessed by the eportfolio, improving their learning $(62.5 \%)$, including those not having a previous experience with this assessment tool $(81.3 \%)$. Progressively they acquired more confidence in achieving their learning 
goals guided by the teacher team, thanks to the human (tutor) and technological (VLE) resources mediated through the eportfolio (from $62.5 \%$ to $87.5 \%$ ), valuing especially the feedback assessment received in their assignments done during the course (70.2\%). To conclude, students classified the influence of eportfolios on their learning and assessment as a more transparent system that helped them to follow clearly their progress (40\%), considering it as an instrument for learning and assessment -with both pedagogical objectives at the same level- (66\%), which will let them show their learning achievements (84.4\%). This new educative system responded to their needs (86.7\%), being adequate for their course, student profile and specialization grade $(84.8 \%)$. They used all the elements included in their eportfolios, above all the course material, but they also missed other activities such as a "good practices" (70.2\%) among other learning facilities (self-assessment tests, etc.).

\subsubsection{Technological issues in learning with eportfolio}

Regarding technological issues in learning with the eportfolio (see table 4), from the beginning the students placed more value on having for each student their own technological tool and a personalized assessment methodology (72.3\%), than the demoralization experienced using technology and the perception of working with a complex system (27.7\%). They were surprised by the design, structure and organization of the eportfolio, and they started to work on it trying to have a global perception of the VLE following tutor indications and consulting the online tutorial made for the eportfolio. In the long term, students valued the technological use of eportfolio (87.1\%).

\subsubsection{General issues in learning with eportfolio}

The univariate analysis finished with three measures at the end of the semester concerning satisfaction, improvement of learning and eportfolio recommendations.

Students were quite satisfied for having developed their work during the course through the eportfolio (measured in a likert scale from 1 to 7, 1 being least satisfaction and 7 maximum satisfaction, they had a $M=5.21 ; S D=1.041$ ), and they also valued it as a factor that had improved their learning (measured again in a likert scale from 1 to 7,1 being least improvement and 7 maximum improvement, they had a $M=5 ; S D=1.319$ ). Moreover, most of them (89.4\%) recommend for future years, in these instrumental courses, using an eportfolio as a tool for support learning and assessment, although a small percentage of them (10.6\%) still do not agree with this affirmation. The bivariate 
analysis, comparing eportfolio items with genre variable, did not provide any significant statistical difference.

Finally, the exploratory factor analyses undertaken to help to find key learning factors related with digital learner course portfolios used (see table 5). Bartlett's test showed good sphericity $\left(\chi^{2}=165,782, \mathrm{df}=78 ; \mathrm{p}<0,00\right)$ for the main 13 variables selected from the computer experience survey and the last eportfolio questionnaire. To extract the principal components we considered eigenvalues greater than 1 and the oblique (not orthogonal) rotation, because it allows the existence of correlated components, which was possible in this case in relation with ICT and ePortfolio. The rotation converged in 12 iterations for Oblimin (SPSS option for the oblique method of rotation), the factor analyses total variance shown that after rotation five factors were explaining 69,788\% variance, and the scree plot showed that the three main components were contributing considerably to the solution $(51,428 \%)$. Minimum factor loading of 0.4 for each variable was used on the rotated component matrix.

\subsection{Students' overall reflection on eportfolios}

Finally, the qualitative analysis of overall reflections by the students showed that they were evaluating the eportfolio from two dimensions: as a methodology and as a platform. The main codes from "Methodology" (following a frequency order) were: the follow-up, the initial contradictory feeling, learning by tasks, assessment, autonomy, dedication and constancy. The main codes from "Platform" (following a frequency order) were: the facility to do and send the tasks, the technological resources for reflection as self-assessment, the role of the tutor as a facilitator through the eportfolio and the interaction between teachers and students. The eportfolio code families were (in salient order): learning, advantages, innovations, problems, assessment, system, sessions, interaction, expectations, reflections and suggestions.

\section{Discussion}

This exploratory research has reached three dimensions of eportfolio fields of working: the technological, the psychological and the pedagogical, particularly concerning the students' perspective. Firstly, the old well-known educative portfolio system has been 
adapted (Arter \& Spandel, 1992; Lyons, 1998; Mabry, 1999; Klenowski, 2004) to its ICT implementation through a computer-mediated eportfolio, in which a highly organized VLE centred on student activity has allowed them to be the owner of this private space and be responsible for its management. Secondly, the process of adaptation to this new form of learning and assessment has been studied from the university student's perspective, addressing their feelings and opinions about its use during a semester. Thirdly, the pedagogical elements related to the students' adaptation to this new system of being assessed during a semester have been analysed in detail.

\subsection{Computer literacy competencies}

At present, university students who have technology within their reach, use web-based environments for learning in their respective universities, but these are usually more teaching-centred. Moreover, they have competencies to use ICT for their learning, but their satisfaction is still variable. Few experiences have been observed in assessment practices and with a personalized system, probably because of the large number of students per course in a traditional University.

\subsection{Psychological, pedagogical and technological aspects of eportfolio}

The use of a digital learner course portfolio has had a positive influence on university students' opinions, attitudes and self-efficacy from the second month of using it until the end. Their perception started to be more optimistic and useful when they could understand how the platform, the methodology and their activity was working, following instructions from different supports (e.g., a tutor or an online tutorial) and changing progressively some of their learning processes (e.g. working more with digital documents than paper, receiving the tutor's feedback when they sent a scheduled task etc.). However, the expected impact on their learning was not so strong; most of them valued its use positively, but only half of them recognized that eportfolio was a more transparent system, which helped them to follow their progress and receive support in their learning in order to control it (Chen et al., 2001; Zubizarreta, 2004; Stefani et al., 2007), bringing them something new as a personalized assessment system.

In the beginning, the feelings towards the innovation were ambiguous, like other innovative experiences using networking technologies in education. The main advantage of eportfolio from the student's point of view was to have a private VLE 
organized by efolders, characterized by being highly structured and transparent, showing clearly their course activities. But at the same time, the main disadvantage congruently was the dedication required, perceived from the beginning and the complexity of the system that was demanding to learn, the use of a new platform, method of assessment and a more digitalized working. It was surprising that, faced with this autonomous proposal and knowing that students had enough background for learning and being assessed through a computer-mediated proposal, they did not elaborate a personal plan of learning to support their educative process.

They valued strongly knowing the assessment criteria, and they had, in general, positive expectations of eportfolio, even without having any previous experience with it. They also started to value the self-management of their learning during the second month of use, but it seems to be due to the methodology of learning by tasks and not to the eportfolio concept that teachers tried to transmit from the very first class. Besides, students were valuing progressively having resources to support their personal learning, understanding that the educative potential of eportfolios supports their own development of learning products (Stefani et al, 2007).

At the end of semester, students were perceiving eportfolio as a learning and assessment tool, which was giving a response to their needs, in the sense that it was facilitating work and communication adapted to their academic profile and level. To conclude, the eportfolio was enhancing their learning from a personalized perspective based on their own achievements. The main factors extracted from their perceptions, opinions and behaviour were: to experience learning and assessment with ICT, to obtain high satisfaction with an eportfolio system as an extension of their common use of technologies, and to value positively the support received through it.

These results, along with the little literature related to academic eportfolios, are showing a clear effect on students' attitudes and beliefs, which is affecting their self-efficiency during a semester. An impact on their motivation through this process to carry out their learning and assessment, and their opinion about eportfolios as an innovation in University could also be observed. These findings are congruent with other computermediated proposals, although again this positive effect on students' opinion is not directly converted into academic achievement. The main advantage achieved in this 
research has been to introduce an eportfolio to indirectly promote the students' selfmanagement of their learning and assessment; in other words, to strengthen autonomous learning (Wenden, 1995; Scharle \& Szabó, 2000; Little, 2004), a competency for future, lifelong and life-wide learners.

Our research has been focused on demonstrating that the design, implementation and use of eportfolio is a reality that benefits the learning process of university students, and contrary to what could be perceived, the system is not so complex to develop and its impact is immediate and positive in an instrumental subject with a blended learning strategy organised by tasks. It goes along with one line of research which studies the current impact of eportfolios, in organizations such as the British Educational Communications and Technology Agency (BECTA), the European Institute of ELearning (EIfEL), etc.

\subsection{Limitations and lines of future research}

As one of the pioneer empirical research studies carried out with digital learner course portfolio, our approximation to this educative phenomenon has been exploratory, with a pre-experimental design, based on a natural group who used the eportfolio and were longitudinally studied during a semester to obtain a deep understanding about how students learn and are assessed from their perspective. The results are based above all on descriptive univariate analysis, as the bivariate analysis only showed one significant statistical difference. It is also worth highlighting that there were no differences between men and women related to the variables studied. In the last term, qualitative analysis completed the results together with the exploratory factor analysis carried out.

There is very little literature on this type of eportfolio and few studies addressed at finding out the impact on students from their perspective, reinforcing the importance of this research, but at the same time more studies must be done in this line to observe if these results are related to this model of digital learner course portfolio or to the novelty. We think, however, that the data are confirming that our results are due to eportfolio impact, as our present university students are becoming familiar with other VLEs for learning, as in most other countries. 
For future research, this study could be replicated or it could be interesting to work with equivalent groups, and achieve a more controlled study, such as a quasi-experimental or experimental design in order to increment internal validity. If it is possible to apply it in different sequential semesters, a longitudinal study could be done with fewer variables more centred on the main dimensions of impact of eportfolios on students' learning and assessment, thanks to exploratory studies like this that are providing us with information about the initial impact of this technological innovation.

Finally, as academics, we think that it could be interesting to continue with a mixedmethod approach that complements the student's perspective with the teacher's perspective, in order to detect and clarify the implication of this innovation from both sides of the phenomenon framed in the University context.

\section{Conclusions}

The use of digital learner course portfolios in the University is becoming more and more a reality, year on year in our institutions, as it is providing us with an answer to a new educative paradigm, more learner-centred and focused on promoting students' selfmanagement and self-responsibility in the learning process, as life long learners. This study has helped us to know, from the students' perspective, how they adapt their learning process and assessment with an eportfolio, and how it affects enhancing their positive attitudes and self-efficacy in relation to their learning. Therefore, student's academic achievement and autonomy could be in part enhanced through the use of a digital learner portfolio in undergraduate and graduate university courses.

\section{Acknowledgements}

This research is part of a PhD thesis, awarded with an European Mention, which was carried out with the fund of a pre-doctoral grant from the Ministry of Education and Culture of the Government of Spain, awarded to the main author, assigned to Research Group of Virtual Teaching and Learning (GREAV) from University of Barcelona, coordinated by the second author, who has been the director of this scientific work. 


\section{References}

Arter, J.A. \& Spandel, V. (1992). Using Portfolios of Students Work in Instruction and Assessment. Educational Measurement: Issues and Practice, Promavera, 36-44.

Bates, A.W. (2003). Technology, e-learning and distance education (2nd ed.). London: Routledge Falmer.

Barrett, H.C. \& Knezec, D. (2003). e-Portfolios: Issues in Assessment, Accountability and Preservice Teacher Preparation. Proceedings American Educational Research Association, Chicago, April 22.

[http://electronicportfolios.org/portfolios/AERA2003.pdf Retrieved October 2008]

Barrett, H.C. (2004). Differentiating Electronic Portfolios and Online Assessment Management Systems. Proceedings of the 2004 Annual Conference of the Society for Information Technology in Teacher Education (SITE 2004), Atlanta, GE, March [http://electronicportfolios.org/portfolios/SITE2004paper.pdf Retrieved October 2008]

Barrett, H.C. (2005). White Paper: Researching electronic portfolios and Learner Engagement. The REFLECT Initiative: Researching Electronic portfolios: Learning, Engagment, Collboration through Technology. [http://electronicportfolios.com/reflect/whitepaper.pdf Retrieved October 2008]

Cambridge, B. (Ed.) (2001). Electronic portfolios. Emerging practices in student, faculty, and institutional learning. Sterling, VI: Stylus Publishing.

Cambridge, D. (in press). Audience, integrity, and the living document: eFolio Minnesota and lifelong and lifewide learning with ePortfolios. Computers \& Education, in press.

Castelló, M. \& Monereo, C. (2000). L'avaluació per carpetes en el practicum de psicopedagogía. Bellaterra: Servei de Publicacions de la Universitat Autònoma de Barcelona. 
Chen, G-D., Liu, C-C., Ou, K-L., \& Lin, M-S. (2001). Web learning Portfolios: A Tool For Supporting Performance Awareness. Innovations in Education and Teaching International (IETI), 38(1), 19-30.

Chen, G-D., Ou, K-L, \& Wang, C-Y. (2003). Use of group discussion and learning portfolio to build knowledge for managing web group learning. Journal of Educational Computing Research, 28(3), 291-315.

Collis, B. \& Moonen, J. (2001). Flexible learning in a digital world. London: Kogan Page.

Creswell, J.W. (2003). Research design: Qualitative, Quantitative, and Mixed methods Approaches (2nd ed.). Thousand Oaks, CA: Sage.

Cuthell, J. P. (2002). Virtual learning: the impact of ICT on the way young people work and learn. Aldershot: Ashgate.

Del duca, D. \& Duque, G. (2006). A Reflection on Aging: A PORTFOlIO of Change in Attitudes Toward Geriatric Patients During a Clerkship Rotation. Educational Gerontology, 32(8), 605-610.

Dougiamas, M. \& Taylor, P. C. (2002). Interpretative analysis of an internet-based course constructed using a new courseware tool called Moodle. Proceedings of the 2002 Annual International Conference on Higher Education Research and Development Society of Australia (HERDSA), Perth, Western Australia.

[http://dougiamas.com/writing/herdsa2002/ Retrieved October 2008]

ePortConsortium (2003). Electronic Portfolios White Paper, Version 1.0. [http://www.eportconsortium.org/Uploads/whitepaperV1_0.pdf Retrieved October 2008]

Hope, J. (2005). Student PORTFOLIOS: Documenting Success. Techniques Making Education and Career Connections, 79(5), 26-31.

Jafari, A. \& Kaufman, C. (2006). Handbook of Research on ePortfolios. London: Idea Group Reference. 
Kankaanranta, M., Barrett, H.C., \& Hartnell-Young, E. (2001). Exploring the use of electronic portfolios in international contexts. Proceedings of World Conference on Educational Multimedia, Hypermedia and Telecommunications 2001 (pp. 874-876). Norfolk, VA: AACE.

Kimball, L. (1998). Managing Distance Learning - New Challenges for Faculty. In R. Hazemi, S.H., \& Wilbur, S. (Eds.). The Digital University: Reinventing the Academy (pp. 25-38). London: Springer.

Kimball, M. A. (2003). The web portfolio guide. New York: Longman.

Klenowski, V. (2004). Desarrollo de portafolios: Para el Aprendizaje y la Evaluación. Madrid: Narcea

Laurillard, D. (1993). Rethinking University Teaching: a framework for the effective use of educational technology. London: Routledge.

Little, D. (2004). Learner autonomy, teacher autonomy and the European Language Portfolio. In Usages del Nouvelles Technologies dans l'Enseignement des langues Etràngeres: L'Autonomie de l'Enseignant et de l'Apprenant face aux Technologies de l'Information et de la Communication (UNTELE 2004), 17-20 de Mars à l'Université de Technologie de Compiègne, France. [http://www.utc.fr/ untele/ . Retrieved October 2008]

López Fernández, O. (2008). Digital learner portfolio as a tool for innovating assessment in the european higher education area. Interactive Educational Multimedia, $16,54-65$.

[http://greav.ub.edu/iem/index.php?journal=iem\&page=article\&op=view\&path[]=139\& path[]=188 Retrieved October 2008]

Lyons, N. (Ed.) (1998). With Portfolio in Hand: validating the new teacher professionalism. New York \& London: Teachers College Press, Columbia University.

Mabry, L. (1999). Portfolios plus: A critical guide to alternative assessment. Thousand Oaks, CA: Corwin Press. 
Meeus, W, Questier, F., \& Derks, T. (2006). Open source eportfolio: development and implementation of an institution wide electronic portfolio platform for students. Educational Media International, 43(2), 133-145.

Niguidula, D. (1993). The Digital Portfolio, A Richer Picture of Student Performance. Brown University. Studies on exhibitions, N. 13, Providence, RI: Coalition of Essential Schools (CES) National.[http://www.essentialschools.org/cs/resources/view/ces_res/225 Retrieved October 2008]

Pidgeon, N.F. \& Henwood, K.L. (1996). Grounded theory: Theoretical background / practical implementation. In J.T.E. Richardson (Ed.), Handbook of qualitative research methods for psychology and the social sciences (pp. 75-101). Leicester: British Psychological Society Books.

Preston, D. S. (2005). Virtual learning and higher education. Amsterdam: Rodopi.

Schank, R. C. (1997). Virtual Learning. A Revolutionary Approach to Building a Highly Skilled Workforce. New York: McGraw-Hill.

Scharle, Á. \& Szabó, A. (2000). Learner autonomy: a guide to developing learner responsibility. Cambridge: Cambridge University Press.

Sorensen, E. K. \& Takle, E. S. (1999). Distributed collaborative learning across disciplines and national borders: structuring throw virtual portfolios. In C. M. Hoadley \& J. Roschelle (Eds.). Proceedings of the Computer Support for Collaborative Learning (CSCL) 1999 Conference (pp. 575-581). Palo Alto, CA: Stanford University [http://www.hum.aau.dk/ vipol/papers/elsebeth/portfolio.htm Retrieved October 2008]

Spendlove, D. \& Hopper, M. (2006).Using Electronic Portfolios to Challenge Current Orthodoxies in the Presentation of an Initial Teacher Training Design and Technology Activity. International Journal of Technology and Design Education”, 16(2), 177-191.

Stefani, L.; Manson, R. \& Pegler, C. (2007). The educational potential of e-portfolios. Supporting personal development and reflective learning. Oxon: Routledge. 
Tolsby, H. (2001). Digital Portfolio: A Tool for Learning, Self-Reflection, Sharing and Collaboration. [http://www.ia.hiof.no/prosjekter/hoit/html/nr1_00/hakont.html Retrieved October 2008]

Todd, Z., Nerlich, B., McKeown, S., \& Clarke, D.D. (2004). Mixing methodologies in Psychology. The integration of qualitative and quantitative methods in theory and practice. Hove: Psychology Press.

Tosh, D. \& Werdmuller, B. (2005). Creations of a personal learning landscape: homogenizing weblogging, social networking and eportfolios. Proceedings of International Conference of ePortfolio 2005 by European Institute for ELearning (EIFEL), Cambridge, U.K.

Wenden, A. L. (1995). Learner training in context: a knowledge-based approach. System, 23(2), 183-194.

Zubizarreta, J. (2004). The learning portfolio. Reflective practice for improving student learning. San Francisco, CA: Jossey-Bass, Anker Publishing Company, Inc. 